\title{
EFEKTIVITAS MODEL QUANTUM TEACHING DALAM MENINGKATKAN HASIL BELAJAR SISWA PADA MATA PELAJARAN IPS KELAS IX SMP NEGERI 18 KOTA TANGERANG SELATAN TAHUN PELAJARAN 2018/2019
}

\author{
LELI YULIANA \\ SMP Negeri 18 Kota Tangsel \\ E-mail : Leliyulianasmp18@gmail.com
}

\begin{abstract}
ABSTRAK
Berdasarkan observasi yang dilakukan di SMP negeri 18 Kota Tangerang Selatan bahwa dalam proses pembelajaran yang dilakukan selama ini yaitu guru menerangkan materi pelajaran dan siswa hanya mendengarkan sambil mencatat. Pada ulangan harian kelas IX.1 pelajaran IPS. Melihat hasil belajar siswa yang masih rendah maka perlu adanya penggunaan metode yang tepat untuk meningkatkan hasil belajar dan aktivitas siswa. Tujuan penelitian ini adalah untuk meningkatkan hasil belajar siswa SMP Negeri 18 Kota Tangerang Selatan dengan menggunakan model pembelajaran Quantum Teaching. Subjek penelitian dalam penelitian ini adalah siswa kelas IX.1 SMP Negeri 18 Kota Tangerang Selaran 35 siswa. Penelitian tindakan kelas ini dilaksanakan dalam dua siklus. Kegiatan setiap siklus dalam penelitian meliputi kegiatan perencanaan, pelaksanaan, observasi dan refleksi. Metode pengumpulan data yaitu metode tes (dengan pilihan ganda) dan metode non tes (observasi dan dokumentasi). Hasil penelitian ini diperoleh presentase aktivitas siswa pada pembelajaran siklus I dengan kategori baik $(77 \%)$ dan pada siklus II meningkat dengan kategori baik (84\%). Rata-rata kelas yang dicapai pada siklus I adalah 73,89 atau $49 \%$ dan pada siklus II rata-rata kelas meningkat menjadi 80,57 atau 91\%. Berdasarkan hasil yang diperoleh dari siklus I sampai dengan akhir siklus II dapat disimpulkan bahwa penggunaan model Quantum Teaching ini memberikan dampak positif, karena dapat meningkatkan hasil belajar IPS.
\end{abstract}

Kata Kunci: Quantum Teaching, Hasil Belajar, IPS

\section{PENDAHULUAN}

Setiap guru memiliki gaya belajar yang berbeda. Perbedaan gaya mengajar dipengaruhi oleh bebera faktor. Salah satu faktornya tentang penguasan medel pembelajaran. Gaya mengajar yang diterapkan oleh guru sangat berpengaruh pada ketertarikan siswa dalam menyimak materi pelajaran. Oleh karena itu, para guru harus selektif dalam memilih model pembelajaran yang akan digunakan dalam proses kegiatan belajar mengajar. Kurangnya variasi dalam memilih model pembelajaran akan memengaruhi terhadap pemahaman dalam materi pembelajaran siswa terutama konsep-konsep yang abstrak untuk mengembangkan keterampilan berpikir kritis siswa. Maka dari itu, guru harus lebih selektif dalam memilih model yang sesuai untuk menunjang ketuntasan belajar siswa didiknya.

Menurut Saefuddin \& Berdiati (2014,hlm 48) Model pembelajaran adalah kerangka konseptual yang melukiskan prosedur sistematis dalam mengorganisasikan sistem belajar untuk mencapai tujuan belajar tertentu dan berfungsi sebagai pedoman bagi perancang pembelajaran dan para pengajar dalam merencanakan dan melaksanakan aktivitas pembelajaran. Fungsi model pembelajaran sebagai acuan bagi guru dalam melaksanakan pembelajaran, agar tujuan pembelajaran tercapai. Oleh karena itu pemilihan model sangat dipengaruhi sifat dari materi yang akan dibelajarkan, tujuan (kompetensi) yang akan dicapai dalam pembelajaran tersebut, serta tingkat kemampuan peserta didik.

Salah satu penerapan model pembelajarannya adalah dengan menerapkan model quantum teaching. Quantum teaching merupakan usaha guru untuk mengkonsentrasikan berbagai interaksi dalam proses pembelajaran menjadi cara yang dapat mengubah prestasi peserta didik, dengan menyingkirkan hambatan belajar melalui penggunaan cara dan media 
pembelajaran yang tepat, sehingga peserta didik dapat belajar secara mudah dan alami. Model pembelajaran quantum teaching diharapkan mampu merangsang kreativitas peserta didik, karena dalam proses pembelajaran peserta didik tidak hanya menerima secara pasif apa yang diberikan oleh guru tetapi siswa diharapkan aktif dan kritis dalam memecahkan masalah pembelajaran. Dengan demikian peserta didik dapat mengetahui manfaat dari materi yang dipelajarinya, sehingga siswa akan lebih termotivasi untuk belajar.

Seperti halnya hasil belajar siswa di SMP Negeri 18 Kota Tangerang Selatan khususnya siswa kelas IX. Pada dasarnya hasil belajar mereka dikatakan masih kurang memuaskan. Menurut pengamatan penulis sebelum melakukan tindakan kelas, mereka seringkali kurang aktif dalam bertanya dan menjawab pertanyaan. Dalam menjawab pertanyaan, seringkali tidak sesuai dengan pertanyaan yang diberikan. Seperti dalam jalannya diskusi, siswa lebih terlihat pasif dalam bertanya dan menjawab pertanyaan. Kepasifan peserta didik dalam proses pembelajaran dipengaruhi oleh beberapa faktor. Metode pembelajaran masih menggunakan metode ceramah. Guru lebih aktif dari pada peserta didik. Model pembelajaran hanya bersifat pokus pada guru. Sehingga selama proses pembelajaran tidak melibatkan keaktifan peserta didik.

Pada proses pembelajaran peserta didik diberikan motivasi dan materi. Materi yang disampaikan "Bab 1 Interaksi Antarnegara Asian dan Negara Lainnya" di kelas IX.1 SMP Negeri 18 Kota Tangerang Selatan. Adapun Kriteria Ketuntasan Minimal 78. Hasil belajar yang diperoleh nilai rata-rata 61,31. Nilai tertinggi yang diperoleh peserta didik 78 dan nilai terendah 50. Peserta didik yang mencapai KKM sebanyak 3 orang atau 9\% dan yang belum mencapai KKM sebanyak 32 orang atau 91\%. Perolehan hasil belajar siswa tersebut menggambarkan bahwa pembelajaran IPS di kelas IX.1 dengan menggunakan metode ceramah tidak efektif.

Oleh karena itu, untuk meningkatkan hasil belajar siswa penelitian tindakan kelas dilakukan. Model pembelajaran yang digunakan quantum teaching. Model pembelajaran quantum teaching yang bersandar pada konsep "bawalah mereka ke dunia kita, dan antarkan dunia kita ke dunia mereka, merupakan model pembelajaran yang menekankan kegiatan pembelajaran yang aktif dan menyenangkan." Penggunaan model pembelajaran quantum teaching diharapkan pembelajaran IPS kelas IX.1 akan lebih bermakna dan menyenangkan. Berdasarkan masalah tersebut maka akan dilakukan penelitian tindakan kelas dengan judul "Efektivitas Model Quantum Teaching Dalam Meningkatkan Hasil Belajar Siswa Pada Mata Pelajaran IPS Kelas IX SMP Negeri 18 Kota Tangerang Selatan Tahun Pelajaran 2018/2019

\section{METODE PENELITIAN}

Penelitian ini menggunakan model spiral dari Kemmis dan Taggart yang dikembangkan oleh Stephen Kemmis dan Robin Taggart. Penelitian ini akan dilaksanakan dalam dua siklus dengan setiap siklusnya terdiri dari tahapan-tahapan, yaitu : perencanaan (Planning), tindakan dan pengamatan (action and observation), dan refleksi (reflection). 


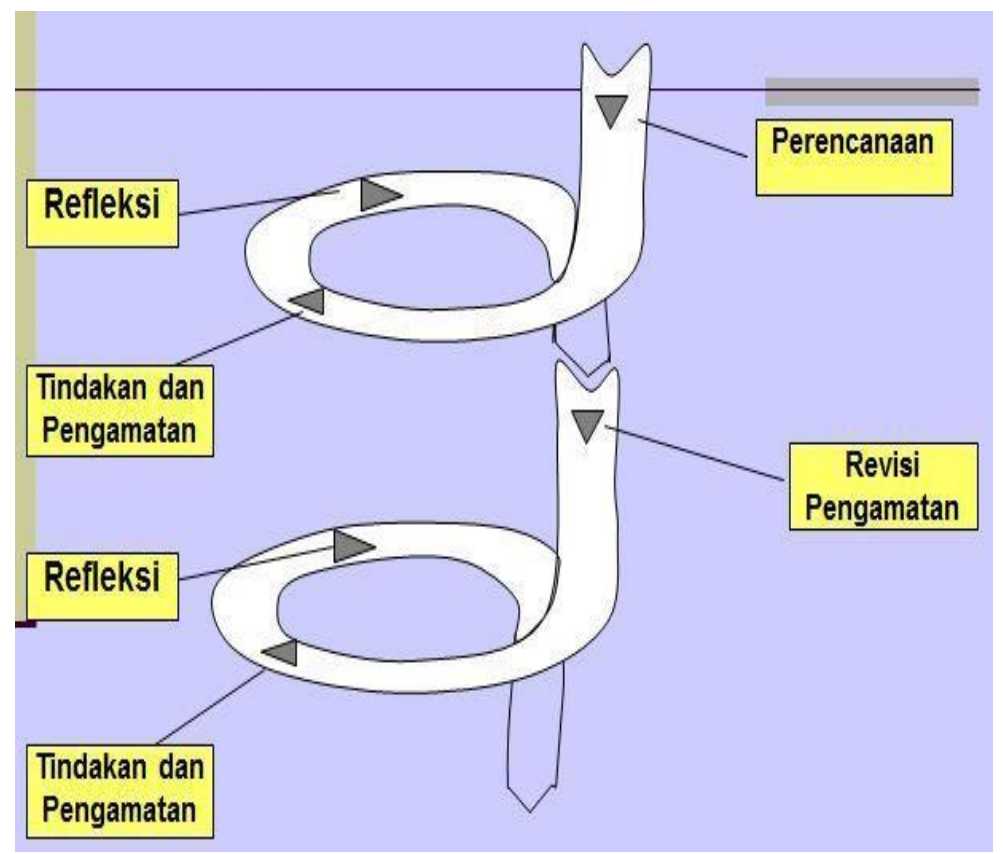

Gambar 1.

Desain Penelitian Menurut Kemmis dan Taggart (Swarsih Madya, 2007: 67)

Dalam pengumpulan data, penulis akan menggunakan beberapa teknik sebagai berikut: teknik observasi , teknik angket, teknik dokumentasi dan evaluasi. Teknik observasi meliputi pengamatan proses belajar dengan penilaian sikap, penilaian pengetahuan dan penilaian keterampilan. Teknik angket dilakukan dengan cara penyebaran angket kepada siswa. Sedangkan teknik dokumentasi dan tes evaluasi dilakukan ketika proses belajar mengajar ada yang didokumentasikan dan adanya evaluasi awal dan akhir.

\section{HASIL DAN PEMBAHASAN}

\section{Hasil Belajar Siswa Pra Siklus atau Kondisi Awal}

Tahap Pra Siklus Ini materi yang diajarkan adalah tentang Interaksi Antarnegara Asia dan Negara Lainnya. Tahap Pra Siklus ini bertujuan Untuk mengetahui hasil belajar siswa dengan menggunakan metode ceramah sebelum menerapkan model pembelajaran Quantum Teaching dalam pembelajaran. Observasi pada tahap Pra Siklus untuk mengetahui kemampuan siswa dalam memahami materi sebelum diterapkannya model pembelajaran Quantum Teaching dalam pembelajaran.

Kompetensi Dasar tentang 3.1 Menelaah perubahan keruangan dan interaksi antarruang negara-negara Asia dan benua lainnya yang diakibatkan faktor alam, manusia dan pengaruhnya terhadap keberlangsungan kehidupan manusia dalam ekonomi, sosial, pendidikan dan politik. Pembelajaran pada pra siklus atau kondisi sebelum dilakukan penelitian, siswa umumnya pasif hanya mendengarkan penjelasan dari guru saja. Untuk menghilangkan kejenuhan banyak di antara siswa yang bermain-main dengan temannya tanpa sepengathuan guru di depan kelas. Bahkan ada juga siswa yang tertidur. Situasi ini terjadi karena suasana yang monoton, siswa pasif, dan tidak ada tantangan bagi siswa. Tes akhir dilakukan, maka sebagian besar hasil belajar siswa di bawah KKM yang ditentukan yaitu 78 . 
Nilai rata-rata yang diperoleh 61,31. Siswa yang tuntas terhadap Ketuntasan minimal yang ditentukan (KKM) yaitu 78 sebanyak 4 orang atau $10 \%$. Siswa yang belum mencapai KKM sebanyak 31 orang atau 90\%. Maka hasil belajar siswa pada pra siklus atau kondisi awal sebelum dilakukannya penggunaan model pembelajaran Quantum Teaching ini 9\%.

Tabel. 1 Distribusi Prosentase Hasil Belajar Pra Siklus atau Kondisi Awal Siswa Kelas IX.1 SMP Negeri 18 Kota Tangerang Selatan Tahun Ajaran 2018/2019

\begin{tabular}{|c|l|l|c|}
\hline Nilai & Frek & $\begin{array}{c}\text { Prosentase } \\
(\boldsymbol{\%})\end{array}$ & $\begin{array}{c}\text { Kategori Prestasi } \\
\text { Belajar }\end{array}$ \\
\hline $91-100$ & - & - & Baik sekali \\
$81-90$ & - & - & Baik \\
$71-80$ & 3 & 8,58 & Cukup baik \\
$61-70$ & 12 & 34,28 & Cukup \\
$50-60$ & 20 & 57,14 & Kurang \\
\hline Total & 35 & 100 & \\
\hline
\end{tabular}

Perolehan hasil belajar 50-60 sebanyak 20 orang atau 57,14\%. Perolehan nilai $61-70$ sebanyak 12 orang atau $34.28 \% \%$. Perolehan nilai $71-80$ sebanyak 3 orang atau 8,58\%. Kategori hasil belajar pada pra siklus belum dikatakan baik, maka dilanjutkan pada siklus I.

\section{Hasil Siklus I}

Tahap pertama pada penelitian ini adalah tahap perencanaan. Mengidentifikasi Standar Kompetensi dan Kompetensi Dasar, Menetapkan Indikator dan Tujuan Pembelajaran. Menyusun Rencana Pelaksanaan Pembelajaran. Mempersiapkan lembar observasi pengamatan pengelolaan pembelajaran dengan menggunakan model pembelajaran Quantum Teaching untuk guru dan siswa. Menata ruangan kelas agar nyaman saat digunakan siswa belajar.

Tabel. 2 Distribusi Prosentase Hasil Belajar Siklus I Siswa Kelas IX.1 SMP Negeri 18 Kota Tangerang Selatan Tahun Ajaran 2018/2019

\begin{tabular}{|c|l|l|c|}
\hline Nilai & Frek & $\begin{array}{c}\text { Prosentase } \\
(\mathbf{\%})\end{array}$ & $\begin{array}{c}\text { Kategori Prestasi } \\
\text { Belajar }\end{array}$ \\
\hline $91-100$ & - & - & Baik sekali \\
$81-90$ & 1 & 2,85 & Baik \\
$71-80$ & 22 & 62,85 & Cukup baik \\
$61-70$ & 12 & 34,28 & Cukup \\
$50-60$ & - & - & Kurang \\
\hline Total & 35 & 100 & \\
\hline
\end{tabular}

Perolehan hasil belajar $61-70$ sebanyak 12 orang atau 34,28\%. Perolehan nilai $71-80$ sebanyak 22 orang atau $62.85 \% \%$. Perolehan nilai $81-90$ sebanyak 1 orang atau 2,85\%. Kategori hasil belajar pada siklus I dikatakan baik. Namun pada perolehan nilai rata-rata masih dibawah $75 \%$ atau $\leq 75 \%$, maka penelitian ini dilanjutkan pada siklus II.

\section{Hasil Siklus II}

Kegiatan awal pada siklus II diawali dengan guru membuka pelajaran dengan salam dan berdoa bersama-sama. Selanjutnya guru melakukan presensi kelas serta menanyakan kabar siswa. Guru melakukan apersepsi dengan menunjukkan hpnya dan bercerita sambil melakukan tanya jawab dengan siswa. Pada siklus II ini sudah mulai nampak beberapa siswa yang menanggapi pertanyaan-pertanyaan dari guru. Selanjutnya guru memotivasi belajar siswa dengan prinsip "AMBAK", yaitu ketika proses pembelajaran berlangsung siswa diberi penjelasan tentang tujuan mempelajari materi dan manfaatnya bagi siswa. 
Tabel 3. Distribusi Prosentase Hasil Belajar Siklus I Siswa Kelas IX.1 SMP Negeri 18 Kota Tangerang Selatan Tahun Ajaran 2018/2019

\begin{tabular}{|c|l|l|c|}
\hline Nilai & Frek & $\begin{array}{c}\text { Prosentase } \\
(\mathbf{\%})\end{array}$ & $\begin{array}{c}\text { Kategori Prestasi } \\
\text { Belajar }\end{array}$ \\
\hline $91-100$ & - & - & Baik sekali \\
$81-90$ & 11 & 31,42 & Baik \\
$71-80$ & 23 & 65,71 & Cukup baik \\
$61-70$ & 1 & 2,85 & Cukup \\
$50-60$ & - & - & Kurang \\
\hline Total & 35 & 100 & \\
\hline
\end{tabular}

Perolehan hasil belajar $61-70$ sebanyak 1 orang atau 2,85\%. Perolehan nilai $71-80$ sebanyak 23 orang atau $65.71 \% \%$. Perolehan nilai $81-90$ sebanyak 11 orang atau 31,42\%. Perolehan rentang 71 -80 lebih banyak dibandingkan pada siklus I. Kategori hasil belajar pada siklus II dikatakan baik. Perolehan nilai rata-rata di atas $75 \%$ atau $\geq 75 \%$, dengan demikian penelitian ini dihentikan.

\section{Respon Dalam Kegiatan Belajar}

Berdasarkan hasil penelitian bahwa semua tahapan yang ada dalam pembelajaran dengan model pembelajaran Quantum Teaching sudah dilaksanakan dengan sangat baik dan mengalami peningkatan pada setiap siklusnya baik dari aktivitas siswa, guru, maupun hasil belajaranya. Hasil pengamatan keaktifan siswa dari mulai kondisi awal, siklus I dan siklus II tergambar pada tabel.

Tabel 4. Hasil Pengamatan Keaktifan Siswa

Perbandingan Keaktifan Siswa

\begin{tabular}{|l|r|l|}
\hline \multicolumn{1}{|c|}{ Siklus } & Prosentase & \multicolumn{1}{c|}{ Kategori } \\
\hline Kondisi Awal & $52 \%$ & Kurang \\
\hline Siklus 1 & $75 \%$ & Baik \\
\hline Siklus 2 & $84 \%$ & Baik \\
\hline
\end{tabular}

Hasil analisis penelitian kondisi awal keaktifan siswa kurang baik dan hanya mencapai $52 \%$ akan tetapi pada siklus I mencapai $75 \%$ dan meningkat $23 \%$ sedangkan ada siklus II mencpai $84 \%$ meningkat $41 \%$ dari kondisi aawal kegiatan pembelajaran dengan model pembelajaran Quantm Teaching.

\section{Hasil Evaluasi}

Berdasarkan hasil penelitian bahwa semua tahapan yang ada dalam pembelajaran dengan model pembelajaran Quantum Teaching sudah dilaksanakan dengan sangat baik dan mengalami peningkatan pada setiap siklusnya baik dari aktivitas siswa, guru, maupun hasil belajaranya. Hasil belajar siswa tergambar penulis menganalisis dengan menggunakan SPSS versi 21,0 Dengan cara analisis deskriptif frekuensi hasilnya sebagai berikut: 
TEACHING : Jurnal Inovasi Keguruan dan IImu Pendidikan Vol. 1. No. 2 Juni 2021 e-ISSN : 2775-7188 | p-ISSN : 2775-717X

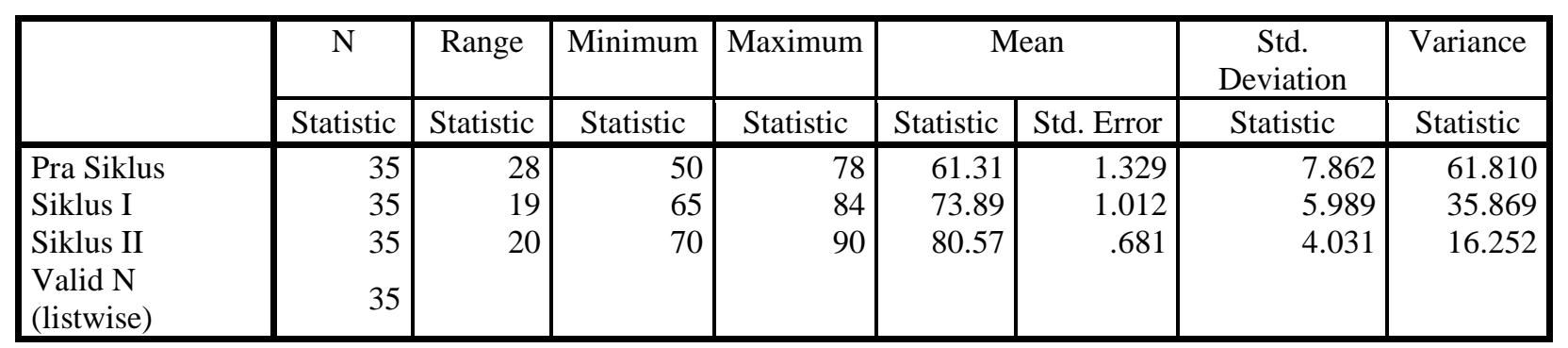

Dari 35 siswa penulis menganalisis hasil belajar pra siklus rata rata nilai 61,31, Range 28, nilai minimal 50 dan nilai maksimal 78. Standar deviasi 7, 862. Pada siklus I setelah penggunaan model pembelajaran Quantum Teaching terjadi peningkatan pada nilai rata-rata 73, 89, Ranger 19, nilai minimal 65 dan nilai maksimal 84. Standar deviasi 5.989. Pada siklus II terjadi penongkatan nilai rata-rata yang signifikan, yaitu 80,57, Range 20, nilai minimal 70 dan nilai maksimal 90, standar deviasi 4.031

Penelitian ini telah membuktikan bahwa ada peningkatan hasil belajar IPS siswa kelas IX.1 dengan menggunakan model pembelajaran Quantum Teaching, namun peneliti menyadari masih terdapat keterbatasan dalam penelitian ini. Penelitian ini dilaksanakan dalam dua siklus karena pada siklus pertama masih terdapat banyak kendala yang dialami. Pada siklus I ratarata kelas belum mencapai KKM yang disepakati yaitu >78 dan partisipasi siswa dalam penerapan model Quantum Teaching belum terlihat sepenuhnya, sehingga peneliti dan guru sepakat untuk melaksanakan perbaikan pada siklus II. Selain itu, hasil belajar terdiri dari berbagai aspek yaitu kognitif, afektif, dan psikomotorik namun dalam penelitian ini peneliti hanya meniliti pada aspek kognitif saja dan tidak meneliti pada aspek lain yang dapat meningkatkan hasil belajar IPS.

\section{KESIMPULAN}

Berdasarkan hasil penelitian yang telah dilakukan dan pembahasan pada bab sebelumnya, dapat disimpulkan bahwa penggunaan model Quantum Teaching dalam pembelajaran IPS dengan menggunakan langkah TANDUR dapat meningkatkan hasil belajar siswa kelas IX.1 SMP Negeri 18 Kota Tangerang Selatan. Penelitian ini dilakukan dalam dua siklus dengan setiap siklusnya terdapat dua pertemuan. Peningkatan hasil belajar siswa ini dapat dilihat dari pencapaian KKM siswa. Pada siklus I telah terjadi peningkatan sebesar $49 \%$ (17 siswa). Sementara itu, nilai rata-rata kelas pada siklus I adalah 73,89 (belum mencapai KKM). Pada siklus II dapat dikatakan telah terjadi peningkatan sebesar 91\% (32 siswa). Rata rata kelas pada siklus II adalah 80,57 (sudah mencapai KKM).

\section{DAFTAR PUSTAKA}

Ade Sanjaya. (2012). "keunggulan dan kelemahan quantum teaching". Diakses dari http://aadesanjaya.blogspot.com/2012/12/keunggulan-dan-kelemahanquantum.html. Pada tanggal 22 Januari 2016 pukul 15.00 WIB.

Ahmad Susanto.(2013). Teori Belajar dan Pembelajaran. Jakarta : Prenada Media Grup.

Anas Sudijono.(2010). Pengantar Statistik Pendidikan. Jakarta : Rajawali Press.

Asri Budiningsih.(2005). Belajar dan Pembelajaran. Jakarta : PT. Rineka Cipta. DePorter

Bobbi. et al.(2008). Quantum Teaching Mempraktikkan Quantum Learning diruang ruang Kelas. Bandung : Kaifa.

DePorter, Bobbi. et al.(2005).Quantum Learning Membiasakan Belajar Nyaman dan Menyenangkan. Bandung : Kaifa.

Heni rahmawati. (2011). Optimalisasi penerapan pendekatan Quantum Learning sebagai upaya peningkatan hasil belajar IPA siswa kelas V SD Negeri Gesing. Skripsi. Yogyakarta : UNY.

Hurlock, B. Elisabeth.(2003). Psikologi Perkembangan Suatu Pendekatan Sepanjang Rentang 
Kehidupan. Jakarta: Erlangga.

https://serupa.id/model-pembelajaran-pengertian-ciri-jenis-macam-contoh/pukul 14:13

Nana Sudjana. (2005). Cara Belajar Siswa Aktif dalam Proses Belajar Mengajar.

Bandung : Sinar Baru.

Oemar Hamalik.(2001). Proses Belajar Mengajar. Jakarta : Bumi Aksara.

Rita eka izzaty dkk. (2008). Perkembangan Peserta Didik. Yogyakarta : UNY Press.

Rusman.(2012). Model-model Pembelajaran Mengembangkan Profesionalisme

Guru. Depok: PT. Rajagrafindo Persada.

Siregar, Eveline \& Hartini Nara.(2010). Teori Belajar dan Pembelajaran. Bogor: Ghalia Indonesia.

Slameto. (2003). Belajar dan Faktor-faktor yang Mempengaruhinya. Jakarta : Rineka Cipta

Suharsimi Arikunto.(2010). Penelitian Tindakan Kelas. Yogyakarta : Aditya Medika.

Sugihartono.(2007). Psikologi Pendidikan. Yogyakarta : UNY Press.

Suyono dkk. (2011). Belajar dan Pembelajaran Teori dan Konsep Dasar. Bandung: Remaja Rosdakarya.

Suwarsih Madya. (2007). Teori dan Praktik Penelitian (Action Research).Bandung : Alfabeta. Wijaya Kusumah dkk.(2011). Mengenal Penelitian Tindakan Kelas. Jakarta : PT. Indeks.

Wina Sanjaya.(2008). Strategi Pembelajaran Berorientasi Standar Proses Pendidikan. Jakarta : Kencana Prenada Media Group. 